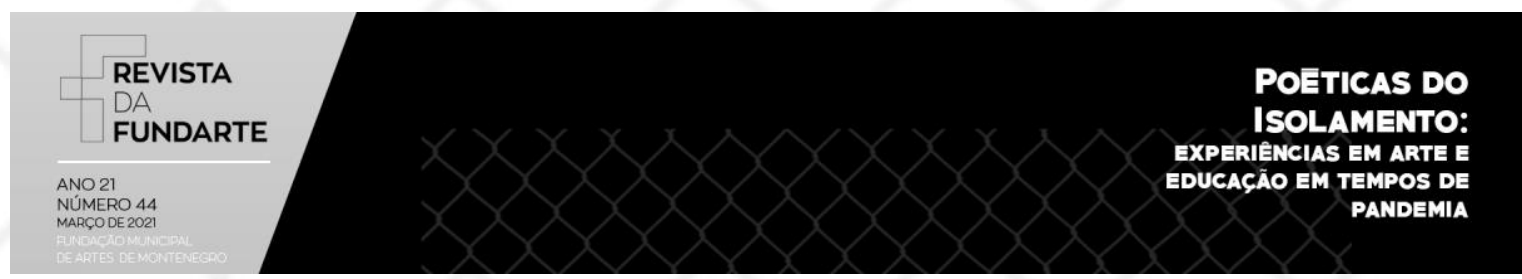

\title{
INSTRUÇÕES POÉTICAS PARA SE RELACIONAR COM OBJETOS COTIDIANOS
}

\author{
Raphael Junior Almeida Batista ${ }^{1}$ \\ Mariana Silva Da Silva²
}

\begin{abstract}
Resumo: O presente artigo relata os processos de um trabalho de conclusão de curso em que se integra a pesquisa artística sobre relações performáticas entre o corpo, espaço e objetos cotidianos. Tensiona a aproximação de objetos que foram inventariados, a partir de protocolos dentro do espaço doméstico, estabelecendo encontros com o corpo e noções de funcionalidades apresentadas em variáveis configurações, a partir de inventários e instruções poéticas. São abarcados conceitos como: funcionalidade, ruptura e performatividade, hibridizando experimentos entre a escrita, performance, fotografia e vídeo, questionando os espaços em que esses objetos podem ser colocados, utilizados ou sobrepostos, em busca, também, de uma relação de confluência com o corpo.
\end{abstract}

Palavras-chave: Performance; Objetos Cotidianos; Instruções Poéticas.

\section{POETIC INSTRUCTIONS TO RELATE TO EVERYDAY OBJECTS}

Abstract: The present article reports on the processes of the author's course conclusion work, which includes an artistic research on performance relations between the body, space and everyday objects. Tensions the approach of objects that were inventoried from protocols within the domestic space, establishing encounters with the body and notions of characteristics in configurations of configurations from inventories and poetic instructions. Concepts such as: functionality, rupture and performativity are

\footnotetext{
1 Graduado em Artes Visuais - Licenciatura pela Universidade Estadual do Rio Grande do Sul (20162021). Foi bolsista no Programa Institucional de Bolsas de Iniciação à Docência PIBID/CAPES/UERGS (2017). Foi monitor do Ateliê Livre de Artes Visuais da UERGS (2017-2018). Foi bolsista na pesquisa "A Licenciatura em Artes Visuais em Vídeos Institucionais de Universidades Brasileiras" IniciE - UERGS(2018), coordenado pela professora Dra. Carmen Capra. Também bolsista da pesquisa "Através da Imagem" vinculado IniciE - UERGS vinculado ao MACRS, coordenado pela professora Me. Mariane Rotter. Foi ministrante de oficinas em Artes Visuais pelo SenacRS em 2018. Teve formação em Mediação pelo programa Educativo da Bienal 12 (2020). Atualmente integra o projeto de pesquisa "O infraordinário como método investigativo em Arte \& Educação" coordenado pela professora Dra. Mariana Silva da Silva.
}

2 Currículo Lattes: Professora Adjunta da Universidade Estadual do Rio Grande do Sul (UERGS). Doutora em Artes Visuais, Ênfase Poéticas Visuais no Instituto de Artes da Universidade Federal do Rio Grande do Sul (UFRGS), com estágio junto à Faculté des Arts da Université de Picardie Jules Verne (Amiens, França). Mestre em Artes Visuais e Bacharel em Artes Plásticas pela Universidade Federal do Rio Grande do Sul (UFRGS). Recebeu Bolsa CAPES Mestrado (2002-2004), Bolsa Unesco Aschberg e Irish Museum of Modern Art para projeto Residência de artista (2008) e Bolsa CAPES PDSE Doutorado Sanduíche (2017). Participa de exposições de artes visuais no Brasil e no exterior desde 2001, é professora universitária desde 2005. Investiga as conexões entre arte, cotidiano e natureza a partir do infraordinário, especialmente no contexto da natureza fluvial dos rios Caí e Guaíba. naminhacidadetemumrio.blogspot.com @comodesenharpedras

ALMEIDA BATISTA, Raphael Junior; Da SILVA, Mariana Silva. Instruções poéticas para se relacionar com objetos cotidianos. Revista da FUNDARTE. Montenegro, p.01-21, ano 21, oํ 44, janeiro/março de 2021.

Disponível em: http://.seer.fundarte.rs.gov.br/index.php/revistadafundarte/index> 30 de março de 2021. 


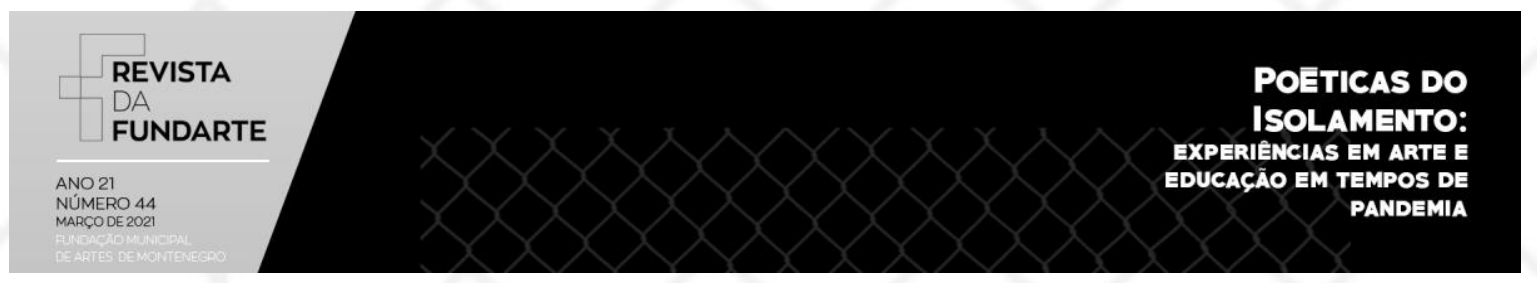

covered, hybridizing experiments between writing, performance, photography and video, questioning the spaces in which these objects can be used, used or overlaid, also looking for a confluence relationship with the body.

Keywords: Performance; Everyday objects; Poetic Instructions.

A pesquisa artística agora apresentada tem como base o cotidiano pandêmico em que nos encontramos em 2020. O cotidiano abriga todas as estruturas de conhecimento, de interação, de relações e construções de identidades possíveis para o entendimento de algo ou até mesmo, alguém. A análise que pode ser feita a partir das ações que acontecem no dia-a-dia, não escapam das relações que mantemos com os objetos que, intrinsecamente, fazem parte dos acontecimentos e de toda a estruturação das camadas sociais que conhecemos. Para Blanchot (2007):

\begin{abstract}
Quaisquer que sejam os seus aspectos, o cotidiano tem esse traço essencial: não se deixa apanhar. Ele escapa. Ele pertence à insignificância, e o insignificante é sem verdade, sem realidade, sem segredo, mas é talvez também o lugar de toda significação possível. O cotidiano escapa. É nisso que ele é estranho, o familiar que se descobre (mas já se dissipa) sob a espécie do extraordinário. É o desapercebido, em primeiro lugar no sentido de que o olhar sempre o ultrapassou e não pode tampouco introduzi-lo num conjunto ou fazer-lhe a "revista", isto é, fechá-lo numa visão panorâmica; pois, por um outro traço, o cotidiano é aquilo que não vemos nunca uma primeira vez, mas que só podemos rever, tendo sempre já o visto por uma ilusão que é precisamente constitutiva do cotidiano. (BLANCHOT, 2007, p. 237).
\end{abstract}

Sendo assim, ao olharmos para o entorno e o cotidiano, é possível se perder e se encontrar, em diversas instâncias, vindo de encontro ao despercebido que possui extremas amplitudes, mas que está sempre apto à suas divergências de sentidos e possibilidades ainda não vistas. Questionamos, então, de que modos o cotidiano pode vir à tona sem perder seu caráter ordinário, a partir de práticas poéticas atravessadas pelo simples ato da observação e da repertorização. E ainda, como inventar e potencializar confluências entre corpo, espaço e objeto nas nuances de uma rotina cotidiana, repetitiva e corriqueira exacerbada pelo confinamento doméstico? com objetos cotidianos. Revista da FUNDARTE. Montenegro, p.01-21, ano 21, no 44, janeiro/março de 2021.

Disponível em: http://.seer.fundarte.rs.gov.br/index.php/revistadafundarte/index> 30 de março de 2021. 


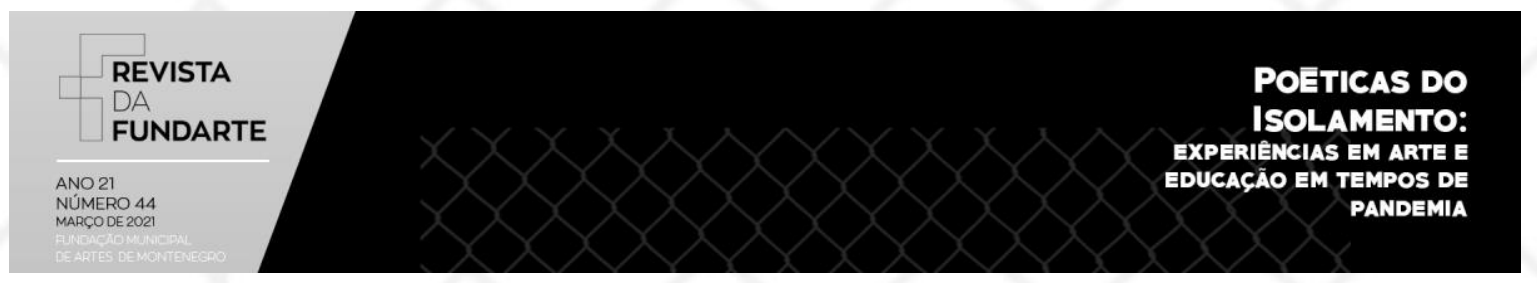

A pesquisa artística, agora analisada, partiu de um lugar restrito ao âmbito doméstico sob 0 isolamento social ocasionado pela COVID-19. Dentro desse contexto, para além de nosso próprio lar e as coisas que ali constituem seus espaços, buscamos refletir e nos abrigar nos entornos que correspondem ao corpo e suas ações. Pairando entre experimentos com o corpo e o seu registro, juntamente das ações desenvolvidas, atribuídas aos objetos cotidianos e do que mais havia ali para ser experienciado, passamos a corresponder aos recursos e abrigos cotidianos enquanto registro, investigação e criação, sem abster-nos do ordinário. Desse modo, conciliamos em nossas práticas as questões apresentadas pelo autor Emanuele Coccia (2020) em que noções atreladas ao lar e às práticas comunais do cotidiano, se devolvem a partir da pandemia. $O$ autor coloca:

\begin{abstract}
Em um mundo onde a política é objeto de proibição e realidade impossível, o que resta são nossos lares: não importa se são realmente apartamentos ou casas de verdade, não importa se são pequenos apartamentos ou grandes propriedades. Tudo se tornou lar. E isso não é uma boa notícia. Nossa casa lar não nos protege. Pode nos matar. Você pode morrer de "lar" em excesso. (COCCIA, 2020, p.2).
\end{abstract}

A estrutura física que compõe o entendimento do que seja um lar tornou-se, de início, uma barreira limitadora para a busca de relações externas e transformouse num conjunto excessivo de paredes e objetos. Enquanto isso, não se buscava entender que, até mesmo essa estrutura que antes era vista como algo limitado, sem a intervenção física e direta do contato social, poderia ser tão infinita de possibilidades de compreensão e atentos ao que deixamos de lado por serem vistos como cotidiano. Pensamos, então, que, o que torna uma possível invenção de usos e maneiras de se relacionar com algo, é a experimentação que pode subverter a lógica moral, pré-estabelecida e a definição que limita o uso de um objeto. Assim como uma criança que explora o mundo ao seu redor, repleto de coisas jamais vistas ou tocadas, usa de seu aval descabido de normas sociais e definições de préusos, para morder, chupar, lamber, jogar no chão, pisar, deitar, amassar, rolar, vestir e comer. com objetos cotidianos. Revista da FUNDARTE. Montenegro, p.01-21, ano 21, no 44, janeiro/março de 2021.

Disponível em: http://.seer.fundarte.rs.gov.br/index.php/revistadafundarte/index> 30 de março de 2021. 


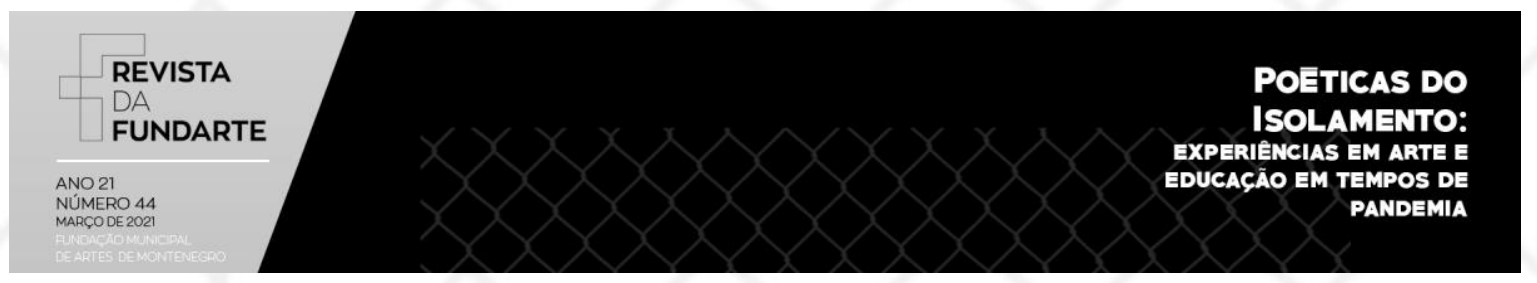

Se toda possibilidade de uso e contato corporal tem sua limitação, mesmo sendo ela inconsciente, pode-se entender que cada objeto existente, para além de sua função, é também um mundo subterrâneo de relações. Essas relações, se constituem fortemente através de pequenos contatos que são proporcionais aos de uma criança, como citado anteriormente. Existem inúmeras coisas não conhecidas por mim e por outrem, e essas coisas podem, também, ser aquilo que não necessariamente, deixam de estar presentes em nossas vivências cotidianas. Assim, é preciso que exista um contato mútuo entre o corpo e o objeto em si. Esse contato, se dá de amplas maneiras, que muitas das vezes, são imperceptíveis. O contato, em um primeiro momento, é a chave para o entendimento de uma coisa para a outra.

Ao pegar uma vassoura, dessas comuns, de madeira que normalmente estão presentes em nossas casas, percebi que durante a limpeza do chão, o meu corpo obteve uma resposta perante a vassoura, ao varrer. A princípio, minha postura inclinou-se para baixo, abrindo uma corcunda que se adaptou ao tamanho do cabo, que por sua vez, é menor que o meu corpo. Percebo, nesse momento, que existe uma troca ativo-passiva ao estabelecer contato com aquele objeto. Ele não se adapta ao meu corpo, mas sim, o meu corpo corresponde a sua estrutura física para o gesto.

A forma que se institui o corpo em contraponto aos objetos com que ele se relaciona, pode se atrelar às suas posições pré estabelecidas socialmente. A artista Glaucis de Morais (figura 1), no processo do seu trabalho, ao realizar uma série de performances em espaços públicos, principalmente com uma vassoura, estabelece diferentes relações com os objetos, pensando em uma série de utilizações e sentidos como a vassoura, que tem sua ligação com a domesticidade e com o feminino. Durante um período de residência artística, na Cité Internationale des Arts, em Paris, no ano de 2010, a artista, ao chegar no ateliê, foi em busca de reconhecimento do espaço que abrigou tantos outros artistas e as marcas de objetos que ali foram deixados. Ao encontrar quatro vassouras, a artista relata: com objetos cotidianos. Revista da FUNDARTE. Montenegro, p.01-21, ano 21, no 44, janeiro/março de 2021.

Disponível em: http://.seer.fundarte.rs.gov.br/index.php/revistadafundarte/index> 30 de março de 2021. 


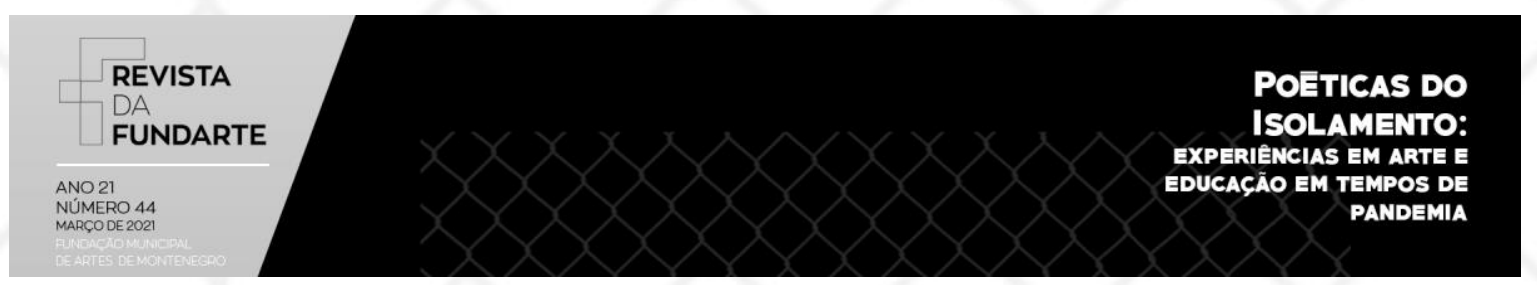

[...]Todas do mesmo feitio, mesmo tipo de cerdas, feitas de madeira crua e áspera, sem requintes, austeras. Diferenciadas pelo tempo de uso, pela força impressa sobre seus corpos afim de levar a cabo a função para a qual foram fabricadas. Marcadas pelos materiais com os quais entraram em contato em uma alquimia de ação, movimento, fricção, produtos químicos e água. Escolhi uma ao acaso, e comecei a varrer o pequeno ateliê/residência. Após algum tempo nesta atividade de gestos repetitivos, comecei a experimentar ludicamente este objeto prosaico, até que ele ficasse em pé sozinho. De um estado ou condição ordinária, própria de um objeto que habita o limiar da invisibilidade por sua desimportância, ele é ressignificado a um quase-sujeito, personagem que se autonomiza de meus gestos por alguns momentos. (ALMEIDA, 2017, p. 33).

Quando existe uma transposição de sentidos de um sujeito-objeto, ao descaracterizar sua função original, é possível abrigar inúmeras e inventivas possibilidades que perpassam sua capacidade limitada. O objeto pode ser a própria personificação enquanto performance e não só enquanto símbolo, mas um próprio protagonista e um corpo que reage aos gestos externos. Entendemos, a partir do trabalho da artista e de nossa experiência artística, que toda estrutura física de quaisquer objetos pode não só tornar-se algo que influencie na forma como o corpo se molda, como também, na configuração de um novo gesto, força física, e postura, que, na maioria das vezes, manifesta-se de modo receptor.

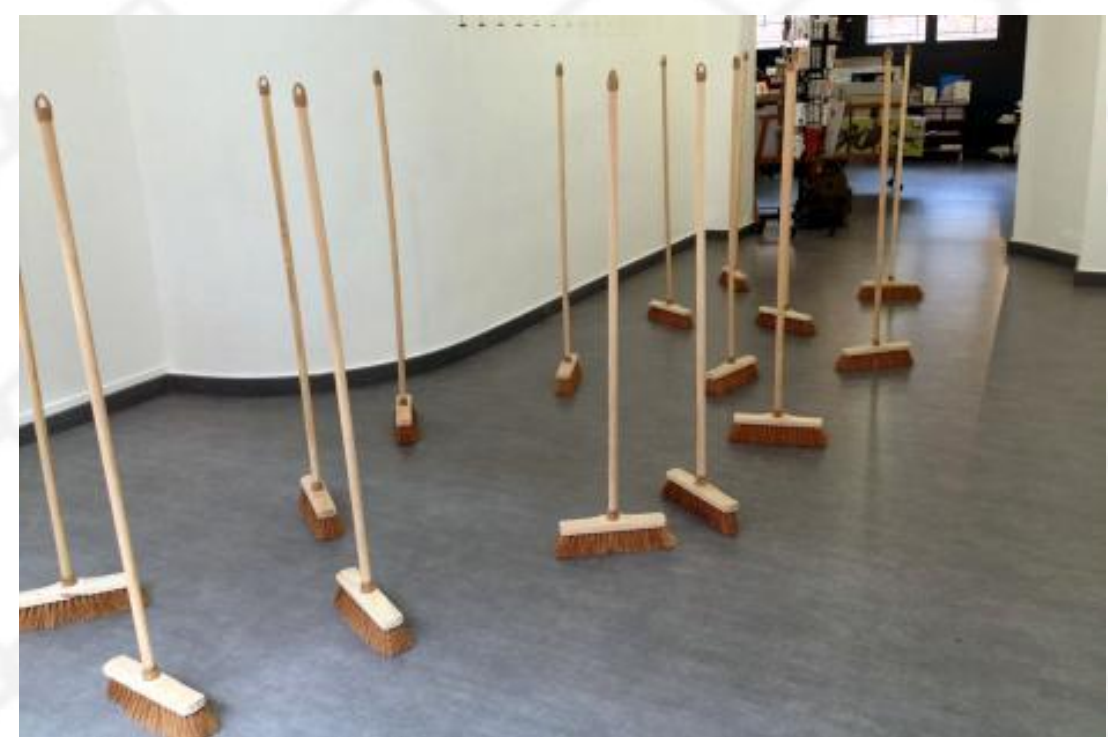

Figura 1: Glaucis de Morais - Inspire...então expire, 2010. Fonte: Divulgação/ PMPA

ALMEIDA BATISTA, Raphael Junior; Da SILVA, Mariana Silva. Instruções poéticas para se relacionar com objetos cotidianos. Revista da FUNDARTE. Montenegro, p.01-21, ano 21, no 44, janeiro/março de 2021.

Disponível em: http://.seer.fundarte.rs.gov.br/index.php/revistadafundarte/index> 30 de março de 2021. 


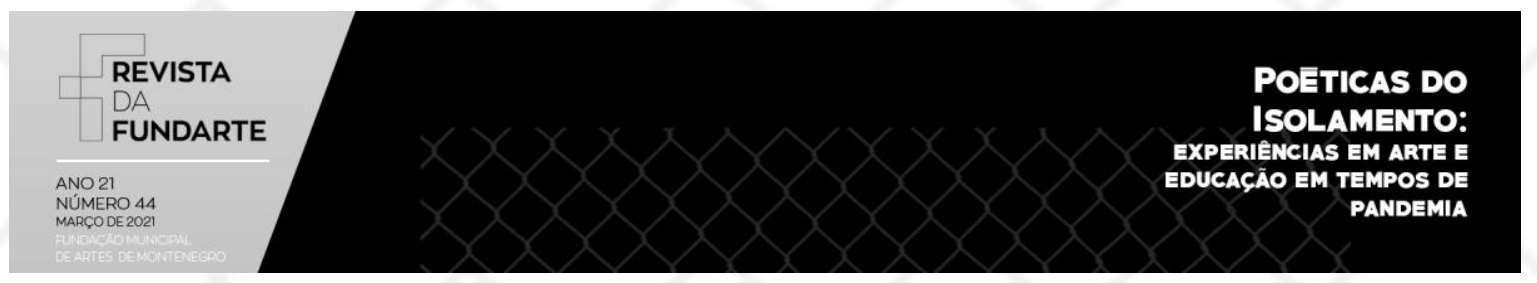

\section{RELAÇÕES PELA BUSCA DO ENTORNO QUE HABITAMOS}

A forma como o corpo do artista, autor da investigação de conclusão de curso, foi tomando presença em relação aos objetos, repetitivamente torna mais visível a provocação sobre nossas funções, nossos sentidos de produtividade e o que os objetos têm como característica social, em função de nós mesmos, não apenas como mera serventia ou utilidade, mas como um corpo presente que pode se contrapor ao nosso, criando noções de identidade, posições sociais, ideológicas, relações de poder, entre outras capacidades submersas num corpo inerte, tal como o objeto.

Bem como o escritor Georges Perec, passamos a desenvolver protocolos diários e semanais que permitem uma maior capacidade de olhar para as coisas de nosso entorno, pensar sobre elas, entender como e o porquê delas estarem ali. No livro Tentativa de esgotamento de um local parisiense, o autor francês investiga as camadas do cotidiano de maneira prática, ao colocar-se como um espectador que explora as possibilidades de registrar o banal, através do olhar, da escrita, dos inventários, do registro de lugares e ações que tomam conta do espaço onde ele se instaura. No prefácio do livro, Ricardo Luiz Silva (2016) diz que:

Condenamos nosso ato de ver ao puro condicionamento mercadológico e espetacular. Vemos o mundo com olhos objetivos, mecanizados, procuramos e decodificamos apenas o funcional e utilitário. [...] Lança-se no vazio, minusculariza a realidade, dá valor ao ordinário e ao inútil. Para o autor, o nada é infinitamente rico que nada pode esgotá-lo, nem mesmo sua ação indiciária narrada no texto. [...] Uma atitude que nos solicita "enxergar" a Cidade. Um ato consciente. Ato que deveria ser realizado à exaustão. Forçar o corpo ao seu limite, o lugar ao seu limite. Estressar o sistema. Conduzir o conjunto a um estado crítico, até a fragilização da aparente estabilidade funcional e organizacional que envolve o lugar. Inutilizá-lo, revelar seu verdadeiro estado. Colocá-lo cru e totalmente disponível à leitura, sem máscaras, empecilhos, representações espetaculares, imagens pré-estabelecidas. Enxergá-lo na sua essência, vulgaridade, realidade, possibilidade. Retirar tudo, até não sobrar nada. Esgotar o lugar. (SILVA, 2016, p. 1-2).

ALMEIDA BATISTA, Raphael Junior; Da SILVA, Mariana Silva. Instruções poéticas para se relacionar com objetos cotidianos. Revista da FUNDARTE. Montenegro, p.01-21, ano 21, no 44, janeiro/março de 2021.

Disponível em: http://.seer.fundarte.rs.gov.br/index.php/revistadafundarte/index> 30 de março de 2021. 


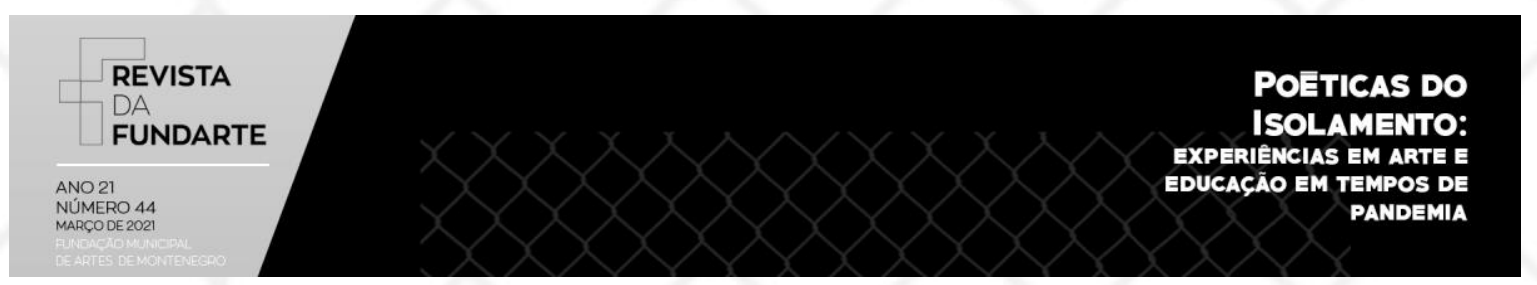

Nesse sentido, o esgotamento se faz, não só sob o estado exaustivo do limite do corpo, mas também, enquanto uma reação permitida por nós mesmos ao observar tudo aquilo que comumente é passado despercebido. O cotidiano, para ser mais específico, existe ali, aqui e agora, sem um roteiro ou uma denominação, ele só é. Ao enxergar e buscar de que formas, de que modos, tal qual, e se, e quantas vezes, e quantas têm ou podem ter cada coisa banal, pode tornar-se excepcional, sem perder o viés da banalidade.

Quando pensamos nos inúmeros objetos que possuímos em nossas casas, entendemos que é preciso um recorte maior para realizar um direcionamento. Objetos cotidianos: entre características que os distinguem e os fazem em comum, esgotados ao olhar diário e listados de maneira neutra, bem como sua imagem fotográfica, ajustada em ordem de uma composição de listas, na tentativa de constituírem um sentido estético. Idealizados separadamente, os experimentos com a escrita vieram a se consolidar como uma parte importante na construção desta pesquisa artística e sua linha cronológica de desenvolvimento. As listas e a construção das instruções aproximam-se igualmente de Perec e seu inventório cotidiano, que tenta esgotar aquilo que é observado.

ALMEIDA BATISTA, Raphael Junior; Da SILVA, Mariana Silva. Instruções poéticas para se relacionar com objetos cotidianos. Revista da FUNDARTE. Montenegro, p.01-21, ano 21, no 44, janeiro/março de 2021.

Disponível em: http://.seer.fundarte.rs.gov.br/index.php/revistadafundarte/index> 30 de março de 2021. 


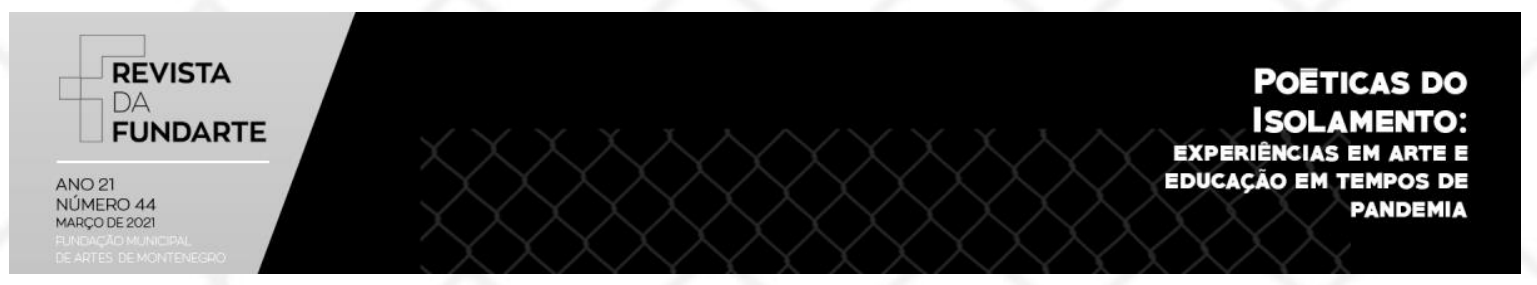

Objeto 1

nome: barbeador

funçã́: remover os pelos do rosto e demais regióes do corpo

nível de interação: $8 / 10$

relação corporal: mãos, mandíbula, sobrancelhas

\section{Objeto 2}

nome: caneca

função: comportar líquidos/bebidas quentes ou frias nível de interaçäio: $10 / 10$

relaçáo corporal: máos, boca, nariz

\section{Objeto 3}

nome: abajur

funçá̃o: iluminar o espaço relativamente ao entorno da cama

nível de interação: $9 / 10$

relaçäo corporal: máos
Objeto 4

nome: linha de costura

função: atar superfícies de pano, juntar tecidos, preencher furos nível de interaçäo: $3 / 10$

relaçĩo corporal: máos
Objeto 5

nome: castiçal

funçáo: comportar uma vela

nível de interaçáo: $4 / 10$

relação corporal: máos
Objeto 6

nome: disco de vinil

função: reproduzir músicas ou decorar o ambiente

nível de interação: $2 / 10$

relaçä́o corporal: máos

\section{Objeto 7}

nome: prato

função: comportar alimentos diversos

nível de interação: 10/10

relação corporal: mãos

\section{Objeto 8}

nome: cadeira

funçä́: sustentar o corpo em assentamento s

nível de interação: 10/10

relação corporal: glúteos, coxas, pernas

Figura 2 - Lista de objetos cotidianos. Fonte: Acervo pessoal, 2020.

Em seguida, o registro se deu através de fotografias, pensando sobre a maneira como cada objeto é representado, através de imagens fotográficas em uma grade, sustentando a ideia inicial da listagem, como também tenta abarcar sua relação de subjetividade. Ao olhar para cada objeto individualmente, é possível analisar características que em um contexto doméstico, talvez não seria possível, sob uma perspectiva que abarque suas relações dentro do espaço.

ALMEIDA BATISTA, Raphael Junior; Da SILVA, Mariana Silva. Instruções poéticas para se relacionar com objetos cotidianos. Revista da FUNDARTE. Montenegro, p.01-21, ano 21, no 44, janeiro/março de 2021.

Disponível em: http://.seer.fundarte.rs.gov.br/index.php/revistadafundarte/index> 30 de março de 2021. 

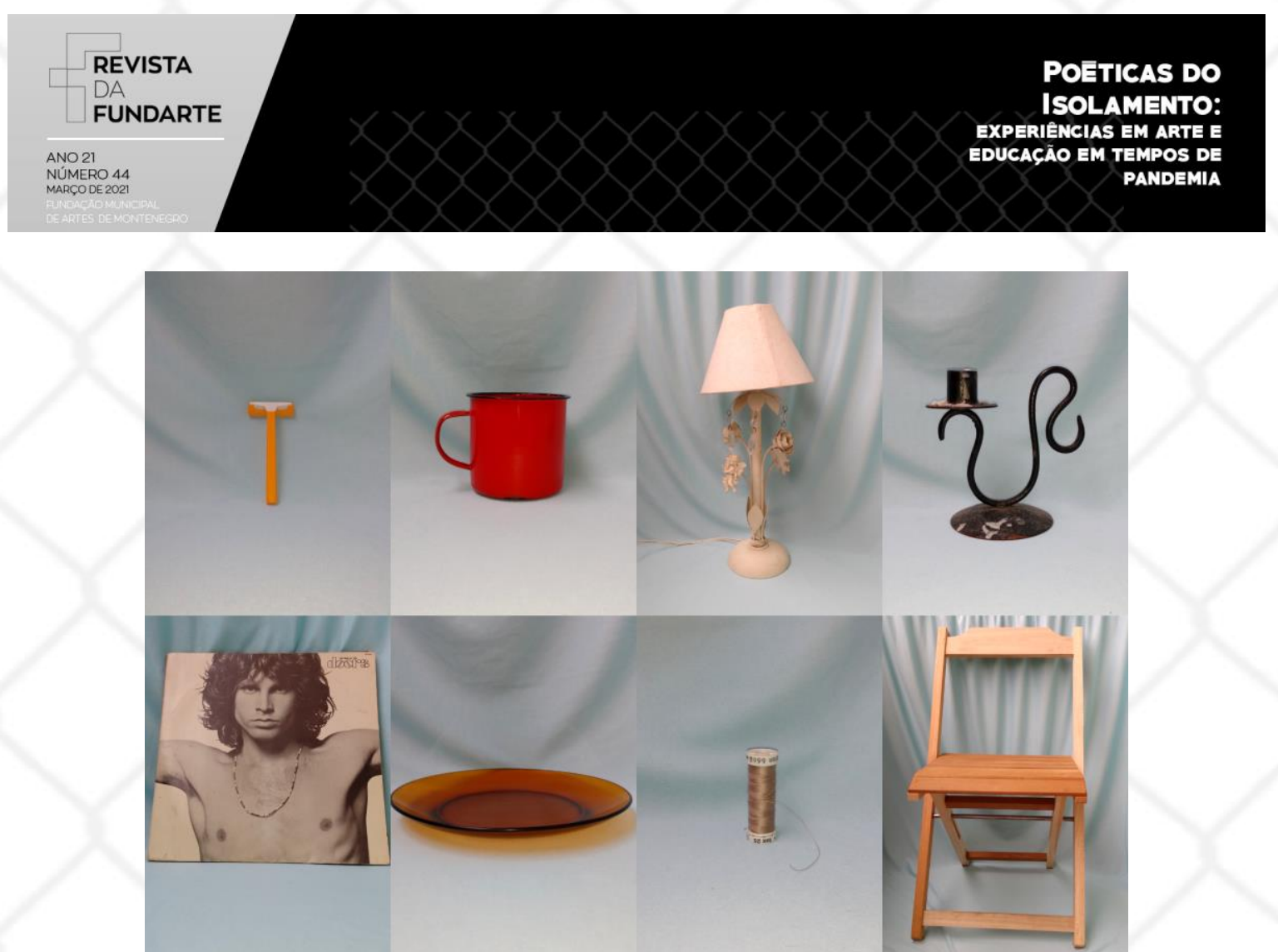

Figura 3 - Série: Objetos Cotidianos. Fotografia. Fonte: Acervo Pessoal, 2020.

O jogo de fotografias dentro de um quadro só ressalta tanto uma característica crua, neutra, como também possibilita a reunião de todas elas dentro de um aspecto seriado, formalizado para receber o contato humano, como um objeto industrial e reprodutível. O que seria de uma cadeira se não existisse um corpo para sustentá-lo? Provavelmente, sua existência não seria possível, ou pelo menos, não da forma que conhecemos. Entretanto, se uma cadeira é apenas uma cadeira, de que outras formas ela pode ser entendida?

Em um dos experimentos realizados a partir dos objetos que foram inventariados, dentro de casa, selecionamos uma caneca, deixando-a totalmente isolada em frente a um fundo neutro. Ao colocá-la numa espécie de estande, analisei suas características formais para deixar que meu corpo guiasse sua interação com a caneca. Dentre inúmeras tentativas, busca-se diferentes formas de encaixar o próprio pé, por exemplo, na parte interior do objeto, a fim de estabelecer uma relação de conectividade que não seja somente a do contato físico, mas que pode atender à lógica da profundidade, do esgotamento, das posições com as quais com objetos cotidianos. Revista da FUNDARTE. Montenegro, p.01-21, ano 21, no 44, janeiro/março de 2021.

Disponível em: http://.seer.fundarte.rs.gov.br/index.php/revistadafundarte/index> 30 de março de 2021. 


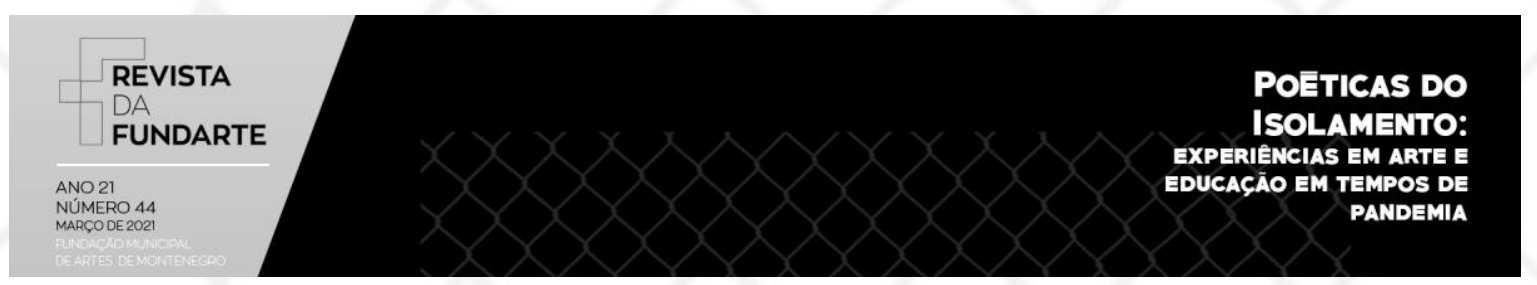

o corpo estaria apto ao encontrar aquela caneca e de que modos seria possível uma compressão de uma coisa com a outra.

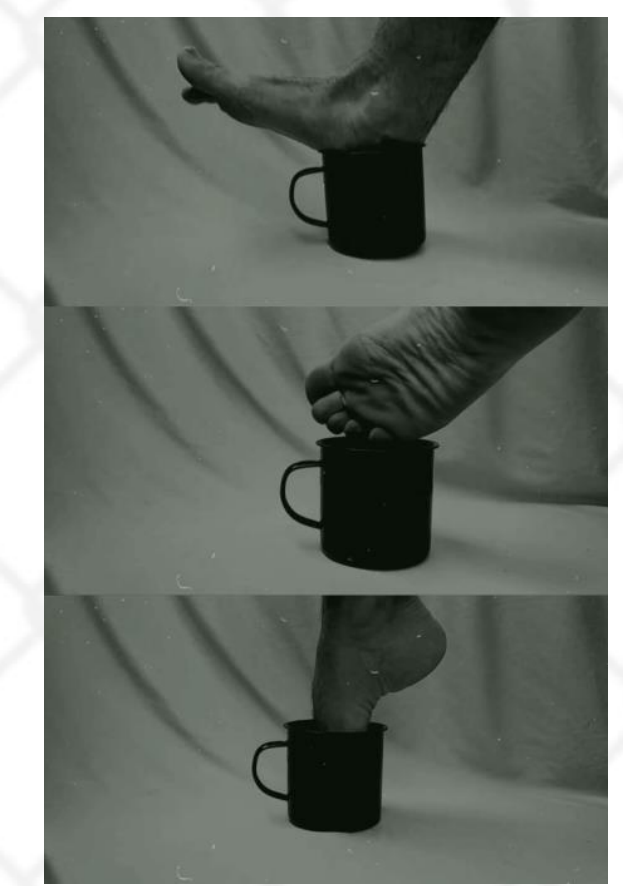

Figura 4 - Limítrofe: Tentativas de encaixe (frames do vídeo). Fonte: Acervo Pessoal, 2020.

O vídeo foi realizado em frames instantâneos que pudessem captar esses momentos em que a tentativa fosse claramente representada. O equilíbrio que pudesse manter o corpo ali presente, estando sob a sustentação de um objeto consideravelmente menor, torna possível as variáveis para as relações entre o encaixe, o esgotamento e a performatividade. Da mesma maneira, utiliza-se outros objetos que seguem o mesmo protocolo onde o corpo se dispõe à presença, e ao contato para uma utilização não usual.

\section{RUPTURAS}

Em dado momento da pesquisa, curiosamente atentamos à uma especificidade que existia nos objetos - não todos - em uma considerável porcentagem presente nos elementos da decoração de uma casa, dos utensílios de com objetos cotidianos. Revista da FUNDARTE. Montenegro, p.01-21, ano 21, no 44, janeiro/março de 2021.

Disponível em: http://.seer.fundarte.rs.gov.br/index.php/revistadafundarte/index> 30 de março de 2021. 


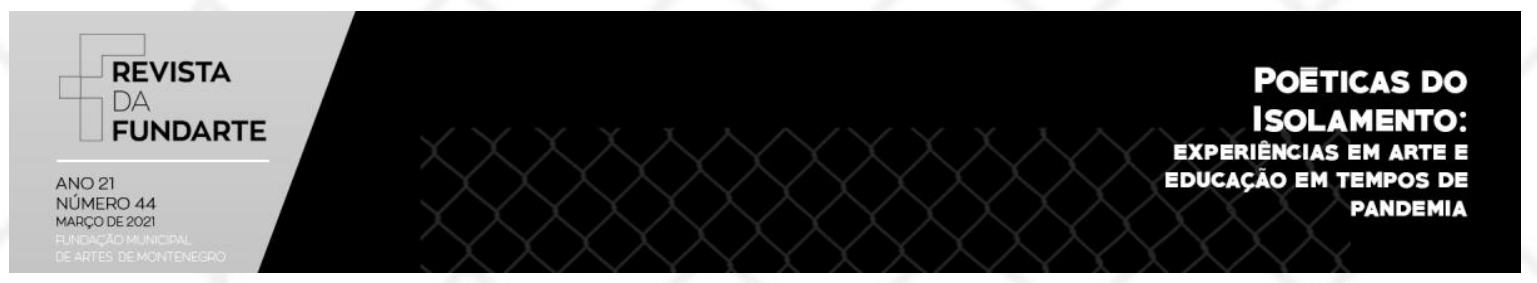

cozinha e de outras coisas que foram reutilizadas. Começamos, então, a pensar sobre os objetos quebrados, o porquê deles estarem ali e quais permanecem artificialmente comprometidos com suas funções originais.

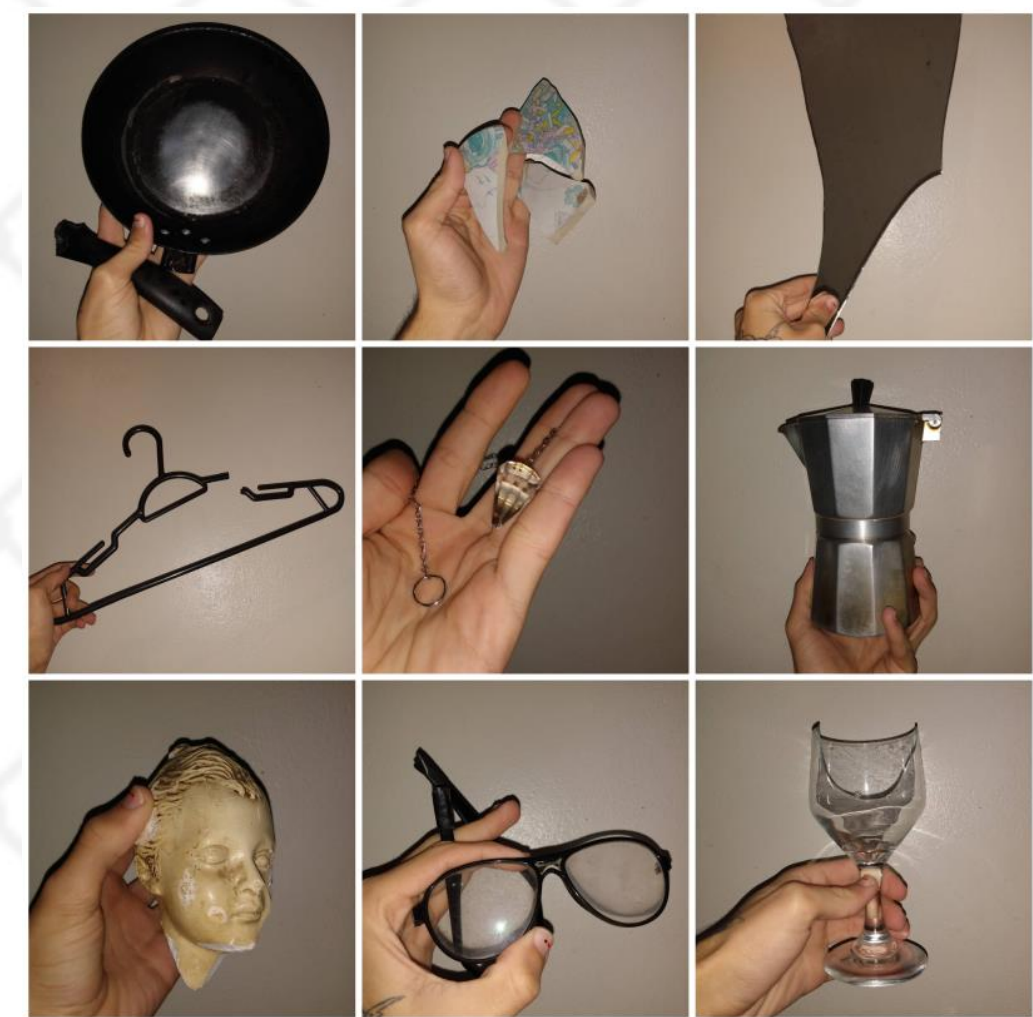

Figura 5 - Inventário de objetos quebrados. Fonte: Acervo Pessoal, 2020.

Tais objetos possuem sua especificidade de criação e uma lógica utilitária que os tornam subjetivos. A partir do momento em que acontece um processo de ruptura, eles já não são mais a mesma coisa. Se pensarmos sobre o que caracteriza cada um individualmente, num primeiro instante, é provável que pensemos em suas funções atribuídas ao seu feito. Estando quebrados, nesse caso, possivelmente serão colocados enquanto inúteis. Logo, esses objetos podem então constituir uma nova identidade que os reúne à uma compreensão distinta. Pensamos nessa relação, a partir do trabalho da artista Mariza Carpes (Figura 6), que na exposição com objetos cotidianos. Revista da FUNDARTE. Montenegro, p.01-21, ano $21, n^{\circ}=44$, janeiro/março de 2021.

Disponível em: http://.seer.fundarte.rs.gov.br/index.php/revistadafundarte/index> 30 de março de 2021. 


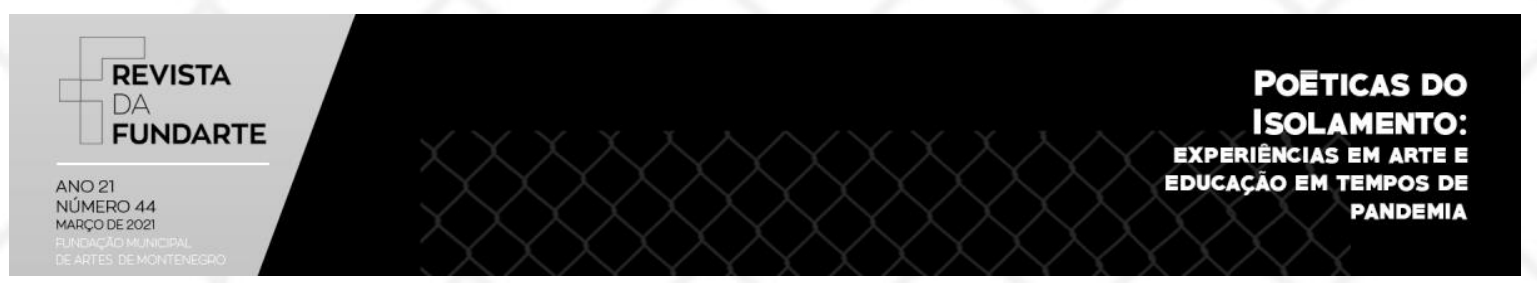

Digo de Onde Venho, apresenta diferentes elementos que tratam das relações de memórias e afetos pessoais de sua própria vivência.

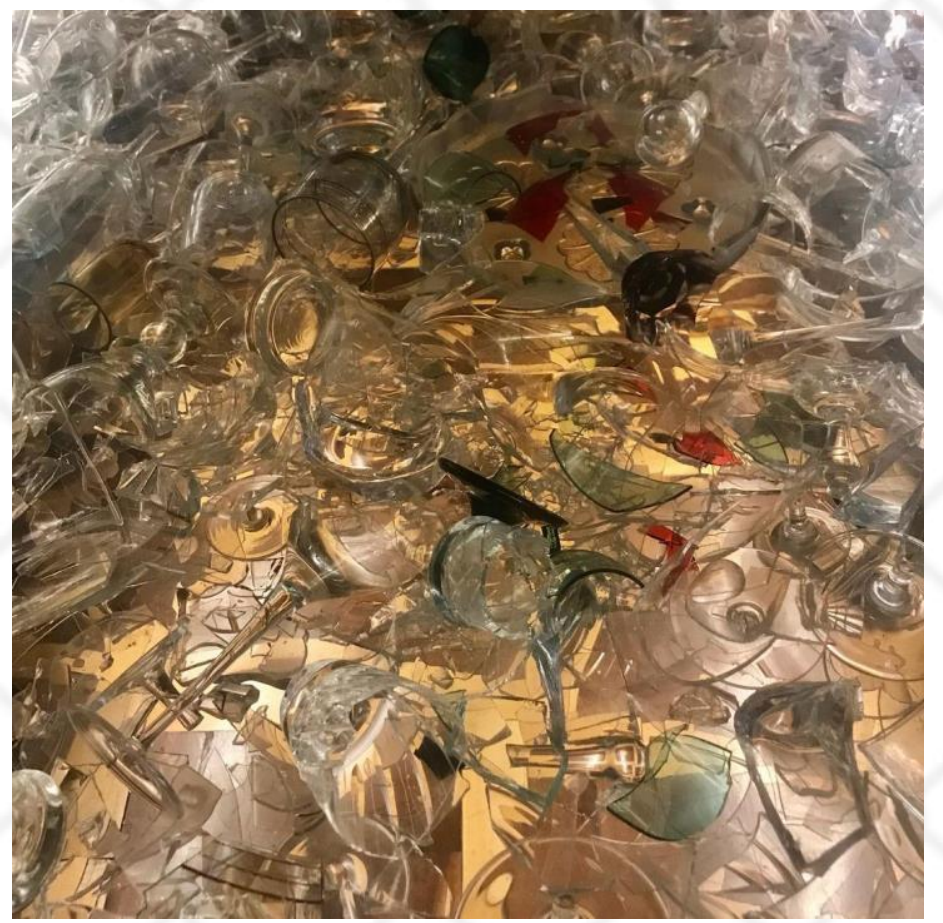

Figura 6 - Digo de onde venho, instalação. Fonte: Mariza Carpes (2019, online).

$\mathrm{Na}$ mesa repleta por cacos de vidro, são apresentados e sobrepostos fragmentos dos copos de cristal oriundos do enxoval da artista, quebrados por um pássaro; dando início a uma coleção que se estende há mais de vinte anos. Em outras instâncias, as relações entre a própria domesticidade, a construção de memórias afetivas para com os próprios objetos em nossas vivências, podem reunir características que fundem noções que perpassam a materialidade e até mesmo, a sua funcionalidade. Sendo assim, entendemos as profundidades que um ou mais objetos mantém em relação a nós mesmos, de acordo com as memórias, as vivências e a fragmentação de algo que se mantém presente enquanto resto, metade ou até mesmo estilhaços, compondo sua inteira existência enquanto memória, sem desprender-se dos consequentes movimentos do tempo e das ações externas. com objetos cotidianos. Revista da FUNDARTE. Montenegro, p.01-21, ano 21, no 44, janeiro/março de 2021.

Disponível em: http://.seer.fundarte.rs.gov.br/index.php/revistadafundarte/index> 30 de março de 2021. 


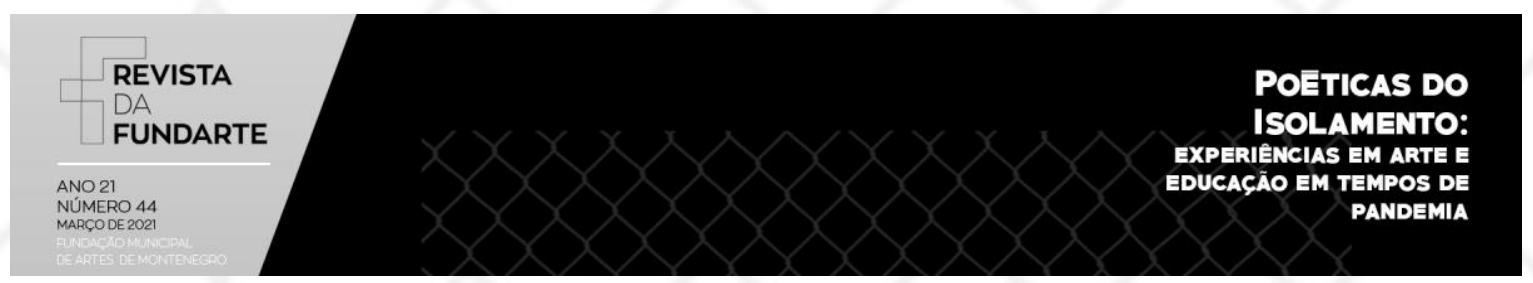

\section{ENTRE A TRANSGRESSÃO E A PERFORMANCE}

O corpo consiste na presença que simula as ações, os gestos e todas as capacidades de movimento e presença, que podem ser apreendidas num espaço e lugar. Sua estrutura é pertencente a uma sociedade, logo, ligada a um sistema que permite o cumprimento e a violação de regras - em suas diversas variações partindo assim, para 0 ato transgressor que esvai as bordas de um limite predeterminado.

Esse limite se instaura dentro do entendimento de performance, enquanto sujeito, objeto, ação e quaisquer características físicas e sensoriais que uma experiência do tipo pode proporcionar, quando uma coisa se sobrepõe a outra, criando assim, imagens e experiências que não podem ser reproduzidas de maneira única. Segundo Glusberg:

As performances não são verossímeis para quem não tenha a experiência com esse tipo de manifestação. Com o termo verossimilhança queremos expressar a ideia de uma adequação entre o percebido e as expectativas do sujeito receptor. Porém, de toda forma, há uma verossimilhança de gênero que vai se constituindo à medida que estas propostas se multiplicam e expandem. A performance não nos apresenta estereótipos preconcebidos e sim criações espontâneas e verdadeiras. (GLUSBERG, 1987, p. 59).

O encontro do corpo com a matéria, possibilita a compreensão de uma relação que não é instituída. Encontramos através da performance, o veículo que potencializa as compreensões do cotidiano e de todas relações que se instauram com o entorno e o que nele se faz presente, mantém-se como mecanismo utilitário e até mesmo a presença, que enquanto forma física, pode ser compreendida de diferentes maneiras. Ao analisar um objeto desconhecido por exemplo, é possível distingui-lo dos demais, ao pensar sobre sua funcionalidade. Essa percepção pode ser desenvolvida, bem como um experimento mental, capaz de elaborar preceitos que caracterizam sua forma física, podendo também, chegar ao possível descarte.

ALMEIDA BATISTA, Raphael Junior; Da SILVA, Mariana Silva. Instruções poéticas para se relacionar com objetos cotidianos. Revista da FUNDARTE. Montenegro, p.01-21, ano 21, no 44 , janeiro/março de 2021.

Disponível em: http://.seer.fundarte.rs.gov.br/index.php/revistadafundarte/index> 30 de março de 2021. 


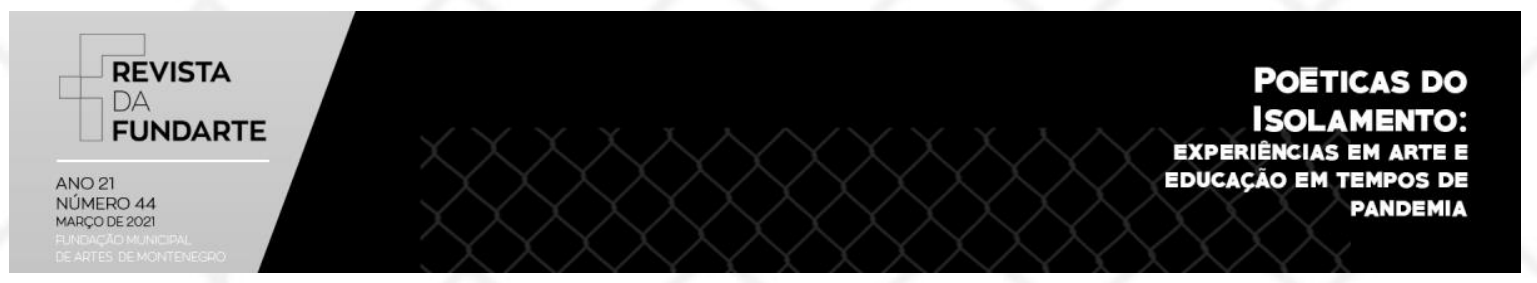

Se formos curiosos, e olharmos para os pequenos detalhes da vida cotidiana e os elementos que nela estão presentes, consequentemente, podemos pensar sobre suas características físicas que, quase predominantemente, necessitam de uma relação corporal. O corpo sendo algo que eminentemente está em movimento, mesmo estático, não deixa de se comunicar com os outros, assim como os objetos Essa comunicação pode se dar de incontáveis maneiras, que nem sequer poder-seia descrever com exata precisão.

Neste sentido, a performance, torna-se um ato visceral para compreender os gestos singelos e banais que cotidianamente estamos acostumados. Ela traz consigo não só uma espécie de representação que faz o uso do corpo, porém, compreende, igualmente, um fluxo contínuo do que já vivenciamos, de todas as ações que já foram feitas, de todos os gestos que já são compreendidos. Desse modo, ela instaura um movimento que não deixa de ser literal, mas, que também abrange novas percepções daquilo que não é novo. Os corpos se diferenciam, assim como os objetos também. Cada um possui sua estrutura, às vezes padronizada, às vezes, nem tanto. O mesmo corpo, contudo, que alcança um livro na estante, pode não ser o mesmo que consegue compreender o que nele está escrito.

Entendemos, assim, a performance no contexto desta pesquisa, partindo de instruções - estas que perpassam a lógica da regra - não somente como um registro da ação, mas a ação que se faz de múltiplas formas em suas subjetividades. Roselee Goldberg diz que:

Qualquer definição mais rígida negaria de imediato a própria possibilidade da performance, pois os seus praticantes usam livremente quaisquer disciplinas e quaisquer meios como material - literatura, poesia, teatro, música, dança, arquitetura e pintura, assim com o vídeo, película, slides e narrações, utilizando-os nas mais diversas combinações. De facto, nenhuma outra forma de expressão artística tem um programa tão ilimitado, uma vez que cada performer cria a sua própria definição através dos processos e modos de execução adotados. (GOLDBERG, p.10, 2006).

ALMEIDA BATISTA, Raphael Junior; Da SILVA, Mariana Silva. Instruções poéticas para se relacionar com objetos cotidianos. Revista da FUNDARTE. Montenegro, p.01-21, ano 21, no 44, janeiro/março de 2021.

Disponível em: http://.seer.fundarte.rs.gov.br/index.php/revistadafundarte/index> 30 de março de 2021. 


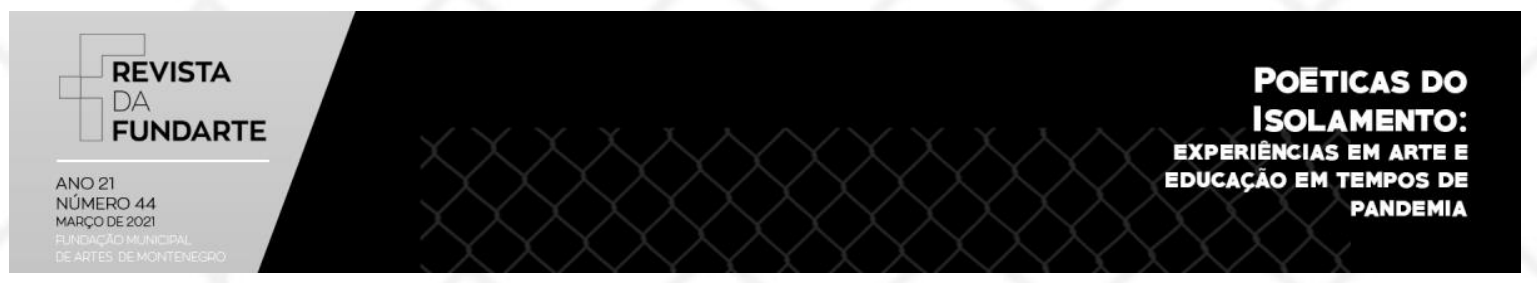

Logo, é possível pensar nas inúmeras adaptações decorrentes de um só movimento que corresponde ao entendimento e execução da performance. Ela se dá de diferentes maneiras, como também podendo mesmo não ser executada a uma plateia. Sua própria definição vai de acordo com quem está se aproximando da linguagem e suas multiplicidades.

\section{INSTRUÇÕES POÉtICAS PARA SE RELACIONAR COM OBJETOS COTIDIANOS}

O uso de instruções, sendo o veículo de apresentação e composição final do trabalho, tendem a relacionar esses dois âmbitos: a vida e a arte, de modo que um não se destaque do outro, de modo que as ínfimas ações e gestos que podem ser executados, permitam uma satisfatória junção de todas as coisas e que toda matéria reunida enquanto corpo, objeto e gesto, pode ser entendida ou incompreendida de maneira singular.

Sendo assim, surgem as Instruções poéticas para se relacionar com objetos cotidianos que, a partir de um método instrutivo e da criação de sentidos relacionais - para além da utilidade dos objetos ordinários -, reestrutura em imagens a pesquisa. As instruções consolidam-se a partir da forma textual, ao encontro do gesto performático entre corpo e objetos. Sendo um método-linguagem utilizado por artistas como Yoko Ono e George Brecht, as chamadas peças, eventos ou instruções, possibilitam uma ponte de aproximação do espectador com a obra e sua possível continuidade no tempo e no espaço. Sua capacidade de interação intensifica, não somente a relação do público, que, por sua vez, é um agente que perpetua a execução de ações, sejam elas efêmeras, registradas, ou, mesmo, permanecendo no mundo das ideias. De acordo com o professor Eduardo Veras:

Às vezes, as instruções no campo da arte nos orientam sobre o conjunto de ações bastante específicas que devem formatar uma situação, podendo com objetos cotidianos. Revista da FUNDARTE. Montenegro, p.01-21, ano $21, n^{\circ}=44$, janeiro/março de 2021.

Disponível em: http://.seer.fundarte.rs.gov.br/index.php/revistadafundarte/index> 30 de março de 2021. 


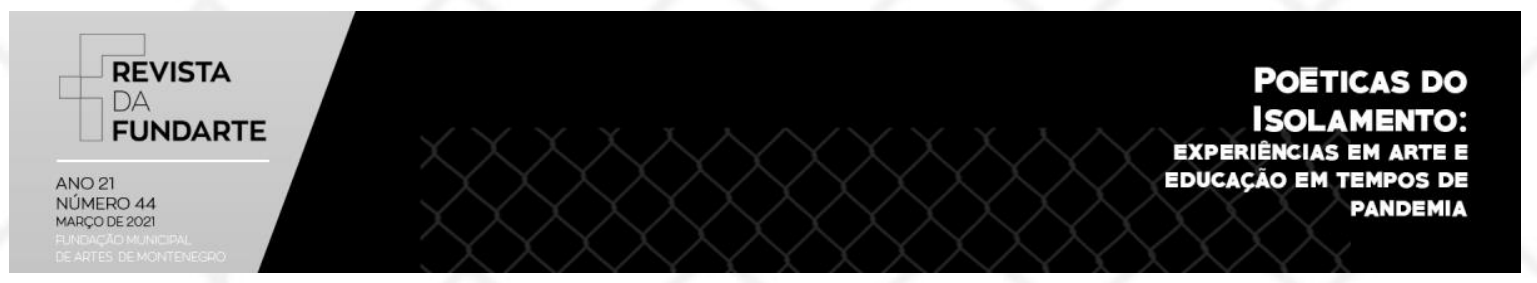

resultar na construção de um objeto ou pelo menos a modificação de um objeto já existente. (VERAS, 2012, p. 14).

Nesse sentido, as instruções escritas para ações com objetos diversos, tornam-se a potência do trabalho artístico desenvolvido, possibilitando uma invenção múltipla entre os objetos e o corpo, como também, entre suas camadas de compreensão. Em seu livro Grapefruit (1964), a artista Yoko Ono (Figura 7), elabora diferentes instruções, as quais se sobressaem nas relações com os objetos, que abarcam suas possíveis compreensões cotidianas e as diferentes relações com 0 corpo, o espaço, as coisas, a imaterialidade e o gesto.

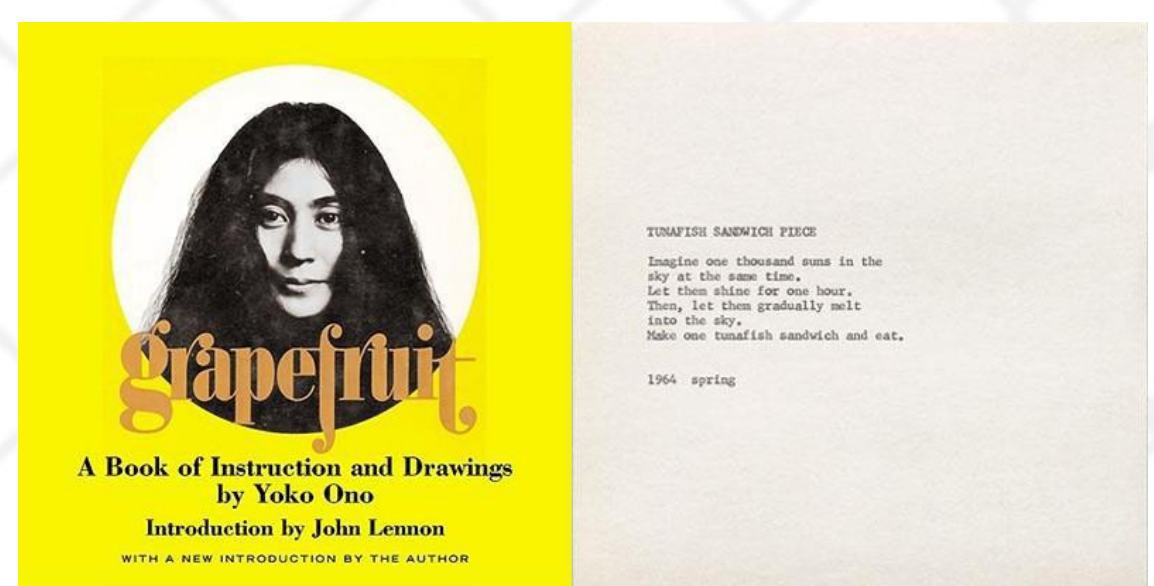

Figura 7 - Yoko Ono, Grapefruit, 1964. Fonte: Barajas (2017, online).

Também sendo um dos integrantes do grupo de artistas Fluxus, o artista George Brecht (Figura 8), insere a escrita como possibilidade de aproximação entre arte e vida, em seus "eventos", que assim como Yoko Ono, propiciaram a escrita instrutiva, de maneira poética, a se relacionar com as coisas, os objetos e a vida de um modo geral. Objetos do cotidiano foram os principais recursos das obras de Brecht. Fazendo o uso de cadeiras, garrafas, cabides, lençóis, blocos de notas e maços de cigarros que tensionam o próprio sistema da arte.

ALMEIDA BATISTA, Raphael Junior; Da SILVA, Mariana Silva. Instruções poéticas para se relacionar com objetos cotidianos. Revista da FUNDARTE. Montenegro, p.01-21, ano 21, no 44, janeiro/março de 2021.

Disponível em: http://.seer.fundarte.rs.gov.br/index.php/revistadafundarte/index> 30 de março de 2021. 

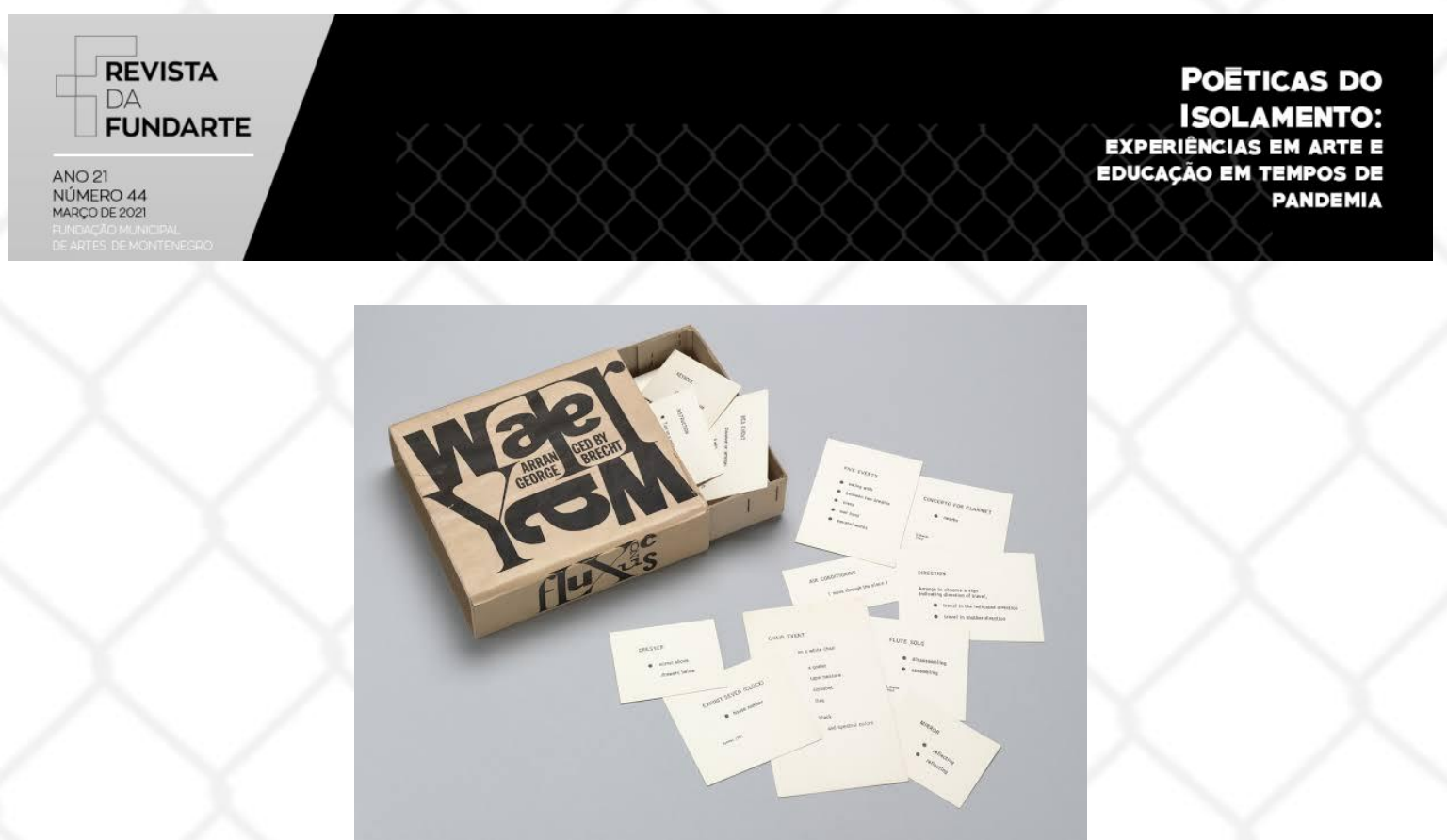

Figura 8 - George Brecht, Water Yam, 1963. Fonte: Museum of Modern Art (2015, online).

Precursor da Arte Conceitual, o artista trabalhou em suas obras os detalhes da vida cotidiana e a forma da experiência participativa do espectador. A experiência oriunda de um contato com a arte para além de uma relação contemplativa proporciona uma intensa relação que não se concentra mais unicamente na visão, na experiência física com a obra, mas que pode alcançar o pensamento e ser um convite à participação. No livro O que é Fluxus? O que não é? O porquê!, Arthur C. Danto (2002) relata sobre um dos integrantes:

George Maciunas, que foi responsável pelo nome de Fluxus e por uma parte considerável de sua forma e sensação, declarou em Neo-Dadá in Music, Theater, Poetry, and Art (Neo-Dada em Música, Teatro, Poesia e Arte) que "Se o homem pudesse ter uma experiência do mundo, o mundo concreto que o cerca, da mesma maneira que tem a experiência da arte, não haveria necessidade de arte, artistas e de elementos igualmente "não-produtivos". A ideia de Maciuna era de que algo poderia ser arte sem necessariamente ser Arte Erudita. (DANTO, 2002, p.25).

Nesse sentido, "desburocratização" da obra de arte e os elementos que nelas são compreendidos enquanto experiência, reforçam, mais do que nunca, a importância de uma desvinculação com aquilo que é pré-concebido, consideravelmente arraigado na produtividade e na própria estética, sendo elementos característicos do mundo fora e dentro da arte.

\section{O TRABALHO ARTÍSTICO}

ALMEIDA BATISTA, Raphael Junior; Da SILVA, Mariana Silva. Instruções poéticas para se relacionar com objetos cotidianos. Revista da FUNDARTE. Montenegro, p.01-21, ano 21, no 44, janeiro/março de 2021.

Disponível em: http://.seer.fundarte.rs.gov.br/index.php/revistadafundarte/index> 30 de março de 2021. 


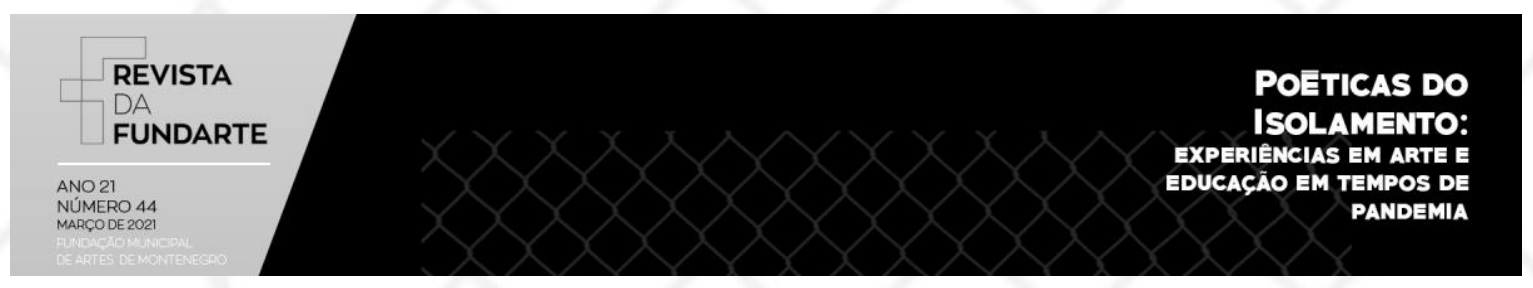

As Instruções poéticas para se relacionar com objetos cotidianos tornam-se um possível mecanismo no que tange à escrita como potência imaginária, não se abstendo da construção de sentidos imagéticos em consonância com a busca por coisas, sua compreensão, a relação que pode ser estabelecida enquanto corpo e a estrutura física que compõe a experimentação de novos sentidos. Instruções podem ser colocadas enquanto algo burocrático e engessado para um único segmento, uma regra. Aqui, entretanto, a tentativa é de que todas as proposições que forem encontradas e experimentadas, possibilitem uma nova ordem do "como fazer", sem uma pretensão técnica ou padronizada, para que um corpo ou outro se coordene com estruturas pré-definidas.

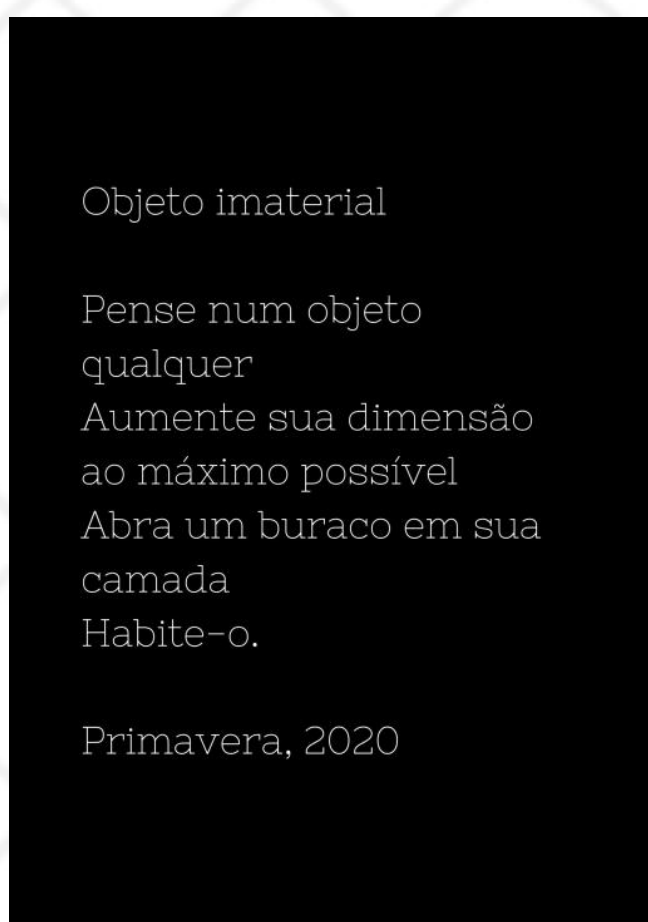

Figura 9 - Instrução poética: Objeto imaterial. Fonte: Acervo Pessoal (2021)

Procura-se uma relação mais próxima do espectador com o trabalho artístico: as Instruções poéticas convidam a gerar uma conectividade para além da observação e da contemplação da obra, tornando possível o exercício da reflexão, com objetos cotidianos. Revista da FUNDARTE. Montenegro, p.01-21, ano $21, n^{\circ}=44$, janeiro/março de 2021.

Disponível em: http://.seer.fundarte.rs.gov.br/index.php/revistadafundarte/index> 30 de março de 2021. 


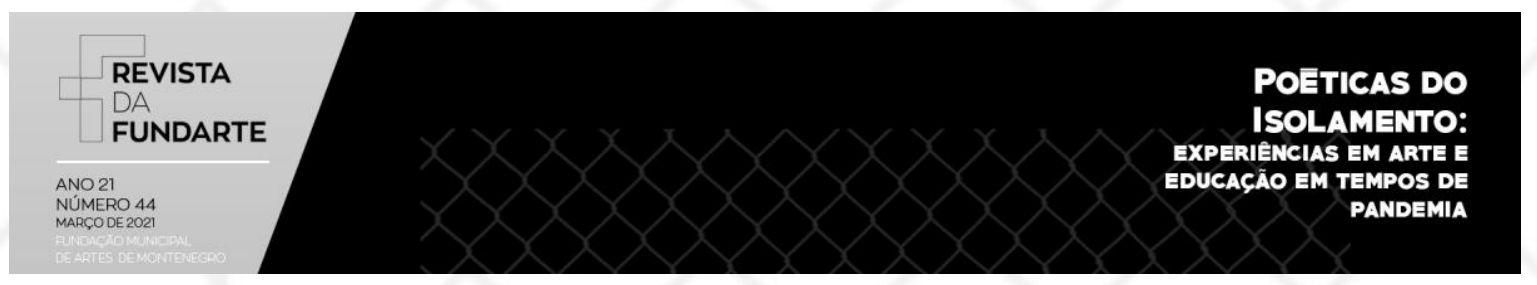

da experiência artística imersa no cotidiano em diferentes espaços da vida e da arte. Com isso, as instruções são entregues como um convite a ultrapassar a própria clareza da escrita enquanto algo linear e objetivo (a forma como a instrução se constrói para ser bem compreendida) em direção à experimentação e à subjetividade de cada leitor do texto. A conjunção de linguagens, que possibilitam uma ação, assim, reforça de maneiras ímpares, as camadas potenciais que se obtêm através de um objeto, sendo ele da arte ou não. As instruções que se conectam juntamente às imagens, são apresentadas individualmente, colocando o propósito de instruir enquanto imagem, sem limitar a compreensão de todo o restante. As ações, através de fotografias e vídeos, não se tornam a essência do trabalho; apresentam, entretanto, uma possibilidade de dar a ver as instruções poéticas em pequenos fragmentos.
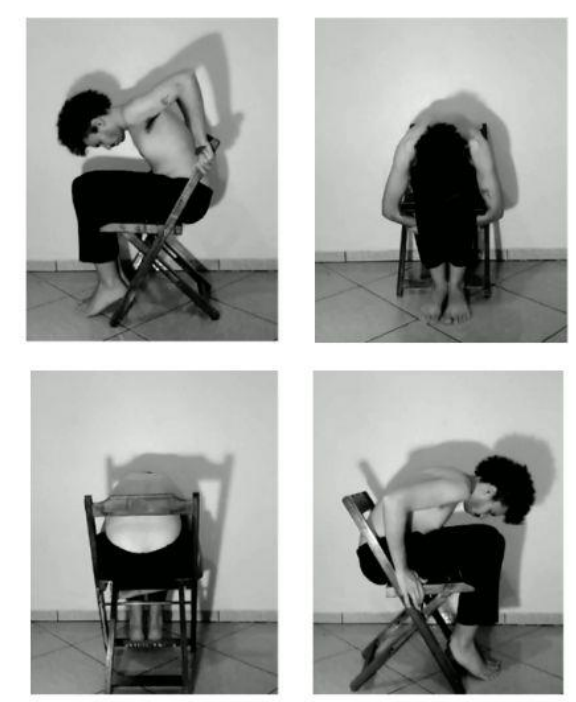

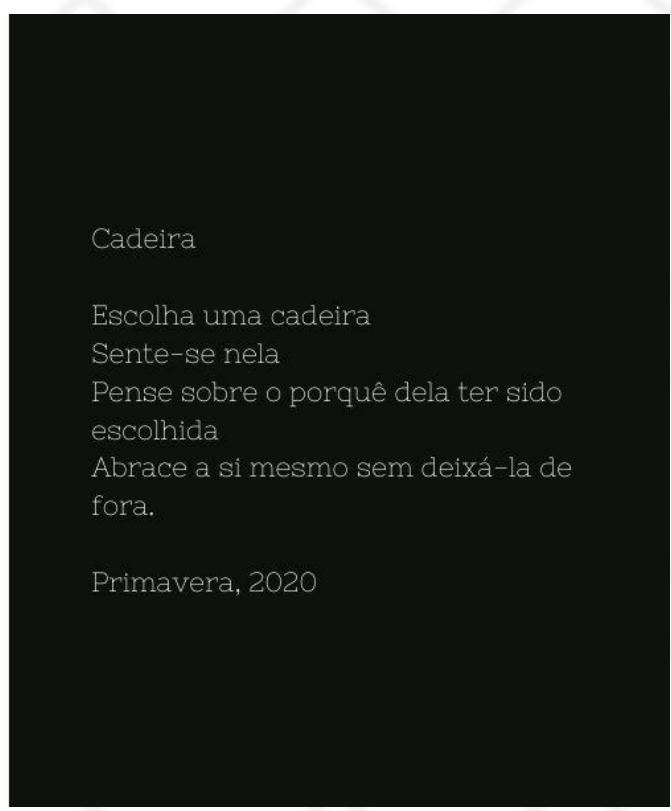

Sente-se nela

Pense sobre o porquê dela ter sido

escolhida

Abrace a si mesmo sem deixá-la de

Primavera, 2020

Figura 10 - Instruções poéticas para se relacionar com objetos cotidianos: Cadeira, 2020. Fonte: Acervo Pessoal.

Tal proposta artística pode ser encarada, ainda, como um convite para pensar, associar e desassociar ideias, realizar instruções, ou até mesmo não realizálas. De todas as propriedades referenciais que sustentam sua defesa, as Instruções com objetos cotidianos. Revista da FUNDARTE. Montenegro, p.01-21, ano 21, no 44, janeiro/março de 2021.

Disponível em: http://.seer.fundarte.rs.gov.br/index.php/revistadafundarte/index> 30 de março de 2021. 


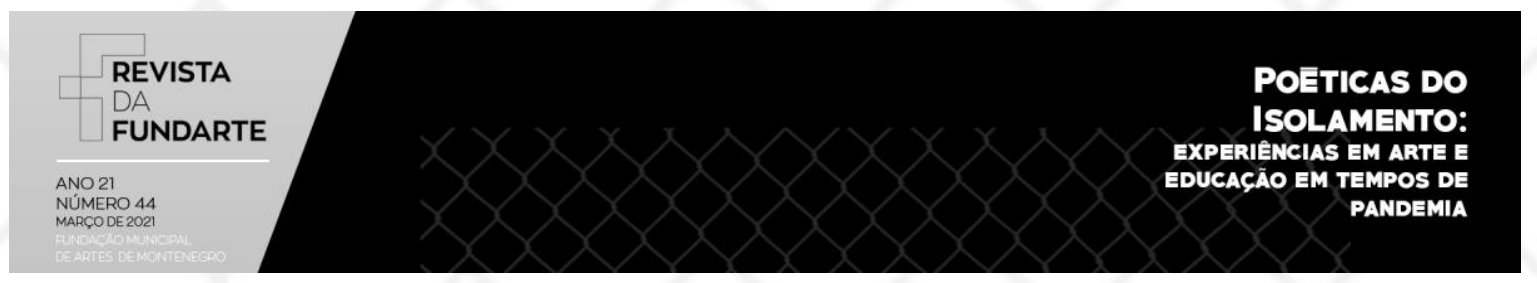

Poéticas para se relacionar com objetos cotidianos perpassam para muito além de uma compreensão fechada, ou mesmo de uma determinação única. Todas as capacidades compreensivas, lógicas, espaciais, contextuais e a bagagem que se sobressai da esfera da regra, do próprio utilitarismo e das limitações do corpo, podem oportunizar uma experiência em arte que não tem a pretensão de inverter papéis - proporcionar aos espectadores "o que é ser artista" ou mesmo "levar" a arte para tal lugar, muito pelo contrário, ela pode ser dissociada de tal pressuposto. Procuramos, muito mais, propor um possível deslocamento, a todos os corpos e objetos ordinários, de atenção ao espaço pandêmico, em que a ordem pode ser, talvez, alterada, borrada ou tensionada poeticamente.

\section{Referências:}

ALMEIDA, Glaucis. Com as palmas da mão e a sutileza do sopro: três exercícios poéticos sobre o equilíbrio. Revista Ciclos , v. 4, p. 31-40, 2017.

BARAJAS, Joshua. Burn this story about Yoko Ono after you've read it. [S.I.], 2017. Disponível em: <https://www.pbs.org/newshour/arts/burn-story-yoko-ono-youveread>. Acesso em: 29 out. 2020.

BLANCHOT, Maurice. A fala cotidiana. In: A conversa infinita 2: a experiência limite. São Paulo: Escuta, 2007.

CARPES, Mariza. Exposição Digo de Onde Venho no Museu de Arte do Rio Grande do Sul reabre! Brasil, 26 out. 2020. Instagram: @Carpesmariza. Disponível em: $<$ https://www.instagram.com/p/CG1lU4sAOdt/?igshid=1bbfsrkvu1pya>. Acesso em: 16 abr. 2019.

COCCIA, Emanuele. Revertendo o novo monasticismo global. Tradução de Mariana Silva da Silva. N-1 Edições: Textos. Disponível em: <https://n-1edicoes.org/109/>. Acesso em: Novembro de 2020.

DANTO, Arthur C. O Mundo como Armazém: Fluxus e Filosofia. In: O que é Fluxus? O que não é! O porquê. Rio de Janeiro: Centro Cultural Banco do Brasil, 2002.

GLUSBERG, Jorge. A Arte da Performance. São Paulo: Ed. Perspectiva. 1987.

GOLDBERG, Roselee. A Arte da Performance. Do Futurismo ao Presente. Trad. Percival Panzoldo de Carvalho. São Paulo: Martins Fontes, 2006.

ALMEIDA BATISTA, Raphael Junior; Da SILVA, Mariana Silva. Instruções poéticas para se relacionar com objetos cotidianos. Revista da FUNDARTE. Montenegro, p.01-21, ano 21, no 44, janeiro/março de 2021.

Disponível em: http://.seer.fundarte.rs.gov.br/index.php/revistadafundarte/index> 30 de março de 2021. 


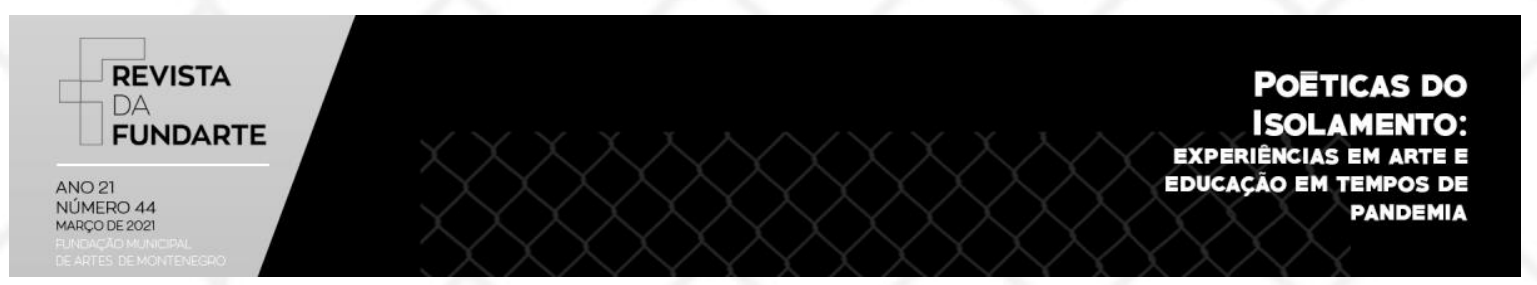

MUSEUM OF MODERN ART. George Brecht. Water Yam. 1963. [2015?]. Disponível em:< https://www.moma.org/collection/works/126322>. Acesso em: 16 jun. 2020.

PEREC, Georges. Tentativa de esgotamento de um local parisiense. Trad. de Ivo Barroso. São Paulo: G. Gili, 2016.

PREFEITURA DE PORTO ALEGRE. Mostra de Glaucis de Morais na Galeria Iberê Camargo. 2016. Disponível em:

$<$ http://www2.portoalegre.rs.gov.br/smc/default.php?p noticia=187231\&MOSTRA+D E+GLAUCIS+DE+MORAIS+NA+GALERIA+IBERE+CAMARGO>. Acesso em: Fevereiro de 2021.

SILVA, Ricardo Luiz. In: PEREC GEORGES. Tentativa de esgotamento de um local pariesiense. Tradução de Ivo Barroso. São Paulo, G:Gili, 2016, p. 1-2.

ALMEIDA BATISTA, Raphael Junior; Da SILVA, Mariana Silva. Instruções poéticas para se relacionar com objetos cotidianos. Revista da FUNDARTE. Montenegro, p.01-21, ano 21, ำ 44, janeiro/março de 2021.

Disponível em: http://.seer.fundarte.rs.gov.br/index.php/revistadafundarte/index> 30 de março de 2021. 